\title{
BIODIREITO, TECNODIREITO E GEODIREITO ${ }^{1}$
}

\author{
BIOLAW, TECHNOLAW, GEOLAW
}

Natalino Irti $^{2}$

1.

O que significa, propriamente, "vida" no Direito de ontem?

Uma simples duração, um intervalo de tempo entre o nascer e o morrer. O Direito não era presente antes do nascimento e, tampouco, depois da morte. Os "momentos" de uma e de outra traçavam limites sagrados e invioláveis. Quando o Direito tinha a necessidade de superá-los, recorria a metáforas e ficções: “conceptus pró jam nato habetur", o concebido se tem já por nascido: se tem, isto é, se dá, se considera, se quer que seja no mundo jurídico. Nascer e morrer pertenciam à natureza, dados por uma realidade externa, que ao direito se impunham na sua incontroversa objetividade.

Um sentimento de mistério envolvia o início e o fim da vida: o sagrado incumbia fosse a alegria do nascimento, fosse a angústia da morte. O Direito estava, em termos, marcado pela natureza, pela forças criadoras e destrutivas que se desenvolviam fora de toda vontade humana. A "integralidade da vida", defendida pelas normas do Direito Penal e elevada a princípio da moderna civilização, ainda indica isto tudo, esta originária inteireza, que ninguém ousa violar e atingir. A "integralidade da vida", em que se respeita e reflete acerca da dignidade da pessoa, é integralidade de todo e qualquer corpo: não do meu ou do teu corpo, mas do corpo como algo indissociável e inerente a qualquer um de nós.

O Direito de ontem, na sua tentativa de proteger a vida humana, tutela e defende o corpo, porque o homem é (ou é também) o seu corpo, esta coisa física e tangível, que as forças destrutivas procuram no nada. O Direito assume a posição de um espectador, perante aquele que desenvolve o teatro do nascer e do morrer. Ele pode pouco ou nada: estender redes de proteção em torno ao mistério de qualquer indivíduo.

Conferência realizada na Faculdade de Direito da Universidade de São Paulo nos dias 23, 24 e 25 de abril de 2007. Tradução de Alfredo Copetti Neto e Karam Trindade.

2 Professor Titular de Direito Civil dell’Universitá di Roma "La Sapienza". O Autor é convidado do Ex-Diretor e Professor Titular de Direito Civil da Faculdade de Direito da Universidade de São Paulo, Antonio Junqueira de Azevedo. 
A técnica não pára perante à vida, nem ao nascer, nem ao morrer, nem ao corpo do homem. Ela domina o mundo e transforma tudo isso que está ao nosso redor nos próprios e indefinidos objetivos. Este domínio reduz cada coisa a um simples objeto, à matéria de cálculo, de controle racional, de capacidade manipulativa. Não existe nada que não seja factível e produzível, não existe nada que não possa ser subtraído às sombras do mistério. A técnica rejeita o acaso e o destino, isto é, as obscuras forças às quais o homem estava submetido no nascer e no morrer.

O corpo adquire um significado diverso, assume uma nova posição no mundo. Paul Valéry, que foi um escritor muito perspicaz e implacável observador do nosso tempo, nos socorre com uma página de Variété, onde distingue três corpos: o primeiro é o-meu-corpo, a coisa presente, que nos pertence e à qual nós pertencemos; o segundo escreve Valéry - "é aquele que é visto pelos outros e é também aquele que nós vimos, mais ou menos, em um espelho ou em um retrato"; e, por fim, tem-se o terceiro corpo, que está aí como junto das partes, feito de pedaços e recomposto à unidade apenas no pensamento. Ora, o terceiro corpo de Valéry é propriamente o corpo da técnica, que não conhece omeu-corpo, nem a visão que outros têm dele, mas considera o corpo, o corpo de qualquer homem, como simples objeto. O corpo da técnica é a estrutura física de uma espécie biológica, que o mundo nos apresenta ao lado das outras estruturas animais e vegetais.

3.

A objetificacão do corpo atinge o seu grau mais alto. O corpo da técnica é o corpo de ninguém: não o meu ou o teu corpo, de um ou de outro, mas o corpo em si, na sua objetiva e indiferente neutralidade. Pesquisas, resultados científicos, aplicações médicas, voltam-se para um corpo sem titular, assim como sem titulares são os produtos que saem das indústrias e as mercadorias ainda não foram colocadas no varejo do comércio. Todas pertencem ao reino dofactível, disso que o homem está em condição, ele mesmo, de manufacere, de retirar do nada ou de colocar no nada.

Pensemos nessa extraordinária e terrível transformação! A vida, em que o homem se encontrava entre a maravilha e a angústia, entre o sentido do mistério e os medos ocultos, é agora um "manufatto", uma coisa do mundo, que ele está em condições de produzir. A palavra decisiva e essencial "produzir" ultrapassa os velhos limites até incluir a vida humana, a vida daquele homem que é, simultaneamente, produtor e produto. A impiedade da técnica revela-se na sua audaciosa grandeza: retira o acaso e o destino da 
vida, entregando-a ao saber calculante do homem. Nascer e morrer não são mais apenas do homem, mas pertencem ao homem; não são mais um simples acontecer, mas um resultado do querer.

Acontecer e querer aparecem em uma antítese radical. A vida é retirada do reino do puro acontecer, dos eventos que o homem encontra fora de si e diante de si, e que, por isso, reinviam a outro (seja a um deus criador ou a uma lei intrínseca à espécie ou, ainda, a um destino enigmático). Não existe necessidade do "outro", pois o homem tomou a vida nas próprias mãos de artífice, colocando-a ao lado de todas as coisas por ele calculáveis e produzíveis. A sua vontade de domínio assume o lugar que, em outras épocas, tinha o acaso, o inesperado, o incompreensível. Como na vida social, o acaso - que decretava a inserção em uma ou outra classe e por isso marcava todo o caminho do singular - é circunscrito ou eliminado com medidas econômicas ou com considerada mobilidade de ofícios e funções; assim, ele é afastado da vida individual; e uma e outra vêm governadas por uma vontade calculadora.

\section{4.}

A vida, liberada do acaso e do destino, sai de sua originária naturalidade e, de certo modo, se torna história dos homens. Não pertence mais à natureza, a um imutável reino que o homem pode apenas observar e conhecer, mas ao processo de saber e aos objetivos do querer. Se chamamos "natureza" uma dada imagem do mundo - a imagem da fé religiosa e da tradição cristã -, então o corpo da técnica é propriamente antinatural, artificialidade do manu-facere que substitui o curso espontâneo das coisas. Não é sem razão que um filósofo italiano, entre os maiores do nosso tempo, Emanuele Severino, escolheu como título de um dos seus últimos livros a abstraia radicalidade do verbo "Nascere". O nascer não é, agora, um dado da natureza, evento externo, que "acontece" ao homem como lhe acontecerá, um dia ou outro, de morrer, mas um resultado técnico, uma construção querida e efetuada por nós mesmos.

E o próprio Severino refere de passagem que este fabricar e destruir a vida tem qualquer coisa de inocente. A inocência da técnica - convém esclarecer -, que dissolve o corpo do destino individual e o observa e estuda na sua objetiva nudeza, sem marcas de pecado e de corrupção. A inocência do produtor, que procura construir e destruir de modo perfeito: eugenética e eutanásia demonstram, em face do advérbio grego eu, o objetivo propriamente da técnica, o escrúpulo do fazer bem, no início e no final da vida. E o advérbio ecoa ainda na palavra "bem-estar", que é mais do que a velha e humilde "saúde": 
"saúde" é sair da doença ou defender-se contra a ameaça à integridade física; "bem-estarv é uma condição do ser, racionalmente calculada e tecnicamente perseguida. A saúde não é mais suficiente; é necessário o bem-estar, que em si inclui também o bem-nascer e o bem-morrer, o nascer são e o morrer sem sofrimento. Fazer "bem", isto é, com perfeição técnica, retirar o homem do nada e restituí-lo ao nada. Esta é a tarefa da técnica, a qual não se pergunta (nem saberia fazê-lo e tampouco responder) sobre o que existiria atrás do nada originário e além do nada final. A técnica não pode escapar de si mesma.

\section{5.}

O que disso tudo faz parte do direito, na medida em que a técnica se apodera do nascer e do morrer humano? No direito, que agora está livre dos vínculos religiosos e metafísicos, tudo se resolve pela vontade impositora do homem? Basta, portanto, perguntar para dar-se conta de que a biotécnica e o Direito pertencem, ambos, ao mundo da vontade humana e são, ainda, formas de vontade de poder. É inútil que a respeito deste ponto se repita aquilo que já foi apresentado em outra lição brasileira: se a biotécnica pretende dominar a vida física do homem, o direito, por outro lado, vincula a sua vontade. Naquela, o domínio sobre o corpo: neste, o domínio sobre a vontade, a fim de que ela se oriente e escolha um determinado modo. Na posição e im-posição de normas é que se expressam as forças históricas da política. ideologias, fé e interesses, que na política se reúnem e agem.

Biotécnica e biodireito são forças da nossa época. Não existe qualquer critério superior que permita decidir entre um e outro, que - fora de um Direito Positivo dado e histórico - admita julgar lícitas ou ilícitas as singulares descobertas e aplicações da biotécnica. Apenas um direito não-positivo, isto é, não posto nem imposto pela vontade humana; não criado pela história, mas revelado além e acima do tempo; apenas um direito assim estaria em condições de, uma vez por todas, estabelecer os limites entre lícito e ilícito e de dizer o sim e o não a singulares experiências da biotécnica. Mas o Direito, do qual o homem moderno dispõe, em que tudo é entregue à vontade, não reconhece vínculos obrigatórios, não atribui qualificações perenes e imutáveis. Então, a relação é propriamente - como já se disse -relação entre duas forças, entre biotécnica e força político-jurídica.

6.

A força político-jurídica não pode mais permanecer restrita aos antigos limites e, tampouco, acolher, de fora, o nascer e o morrer. A juridificação do bios é 
inevitável. A vida, na sua elementar fisicidade e corporeidade, exige regras, faz apelo à decisão política, ultrapassa impetuosamente os limites do Direito. Não um jurista (os juristas caminham a passos pesados e lentos), mas um sensibilíssimo sismógrafo da nossa época, Ernst Jünger, já em 1981 via, nas novas formas de procriação, "sintomas de uma virada do mundo", anotando: "As leis podem apenas agir como barreira ou cavar um leito para a correnteza. Mas que coisa são as leis quando um novo ente projeta a sua sombra? Isso pode ser verificado nos juristas através da falta de referências às quais eles poderiam recorrer. Aquilo que, neste caso, deve ser enfrentado e resolvido não podia prever nem nos códigos de direito civil, nem naqueles de direito penal. Em discussão, de fato, não está apenas uma transformação no campo do direito, como, por exemplo, a mudança do estado civil, mas um evento biológico que tem consequências imprevisíveis". 3

"Agir como barreira" ou "cavar um leito para a correnteza": a alternativa de Jürgen implica, de um e de outro modo, que o Direito tome posição e, então, que assuma a vida, o nascer e o morrer, como coisa própria, como eventos não-recebidos do Exterior, mas previstos e disciplinados pelas normas. Não mais pertencem às ordens espontâneas da natureza, mas às ordens artificiais do direito. Os códigos civis se restringem aos "momentos" do nascer e do morrer, do vir - a pessoa jurídica - do nada e do retornar ao nada. Essencial aquele breve intervalo, que é o viver do homem entre outros homens e com outros homens.

Os problemas da biotécnica levam o direito a termos extremos, a limites já tidos por insuperáveis. Os modos de nascer e os modos de morrer tornam-se matéria de direito e adquirem a necessária rigidez das formas jurídicas. Isso é próprio do Direito: que, ao entrar em contato com experiências de estudo ou de vida, as converte em formas, naqueles modelos abstratos e gerais, que somente permitem dominar a irrepetível variedade das coisas e projetar-se na direção do futuro. Juridificacão significa redução a formas.

\section{7.}

Este é o ponto em que a biotécnica e o biodireito se reencontram no mesmo e idêntico horizonte. Se a primeira assume o corpo na sua física objetividade, o segundo considera seus modos e formas, também objetivos, destacados da singular e irrepetível individualidade. O processo de objetivacão é comum a ambas as forças, as grandes potências que visam governar as coisas e os homens. $\mathrm{O}$ corpo, no seu nascer e morrer, na

3 Í.JÜNGER. Ernst. Al muro dei tempo. Milano: Adelphi, 2000, p. 233. 
sua duração em vida, não é este ou aquele corpo, o meu ou o seu, mas o corpo em si, na sua calculável e manipulável objetividade.

A redução a objeto, a coisa entre as coisas, é inseparável da biotécnica e do biodireito. Não mais o indivíduo inteiro, corpo e pensamento, físicidade e espiritualidade, mas a res extensa, uma matéria experimentável e regulável, sobre a qual se exercita, de um modo ou de outro, a vontade do homem. O nascer e o morrer se tornam, assim, eventos calculáveis: pela racionalidade científica, que os acompanha e determina o seu acontecimento; pela racionalidade jurídica, que, superados os antigos limites, os converte em formas abstraias, em modelos de ações e esquemas gerais. O corpo não é mais a morada de um ente, habitada brevemente e, depois, deixada rumo a outros reinos.

Por uma singular inversão, não escapando das análises mais agudas da modernidade, o extremo subjetivismo - este desfazer-se dos vínculos físicos e religiosos e entregar-se à vontade do homem - transforma-se em extremo objetivismo. A vontade reduz homens e coisas a objetos, a terreno de forças calculáveis e manipuláveis. Se a vida se coloca diante de mim como objeto, então ela se separa do seu portador, do homem concreto e determinado, e se converte em simples matéria de técnica e de regras jurídicas.

8.

A ruptura com a tradição, a descontinuidade dos tempos, assume forma de tragédia. O nascer, que era um pró-vir, um chegar do passado e se mostrar, passando do hoje em direção ao futuro, é agora um evento tecnológico. O mistério está resolvido, se conhece tudo antecipadamente; e, antecipadamente, tudo é interrompível, corrigível, manipulável. A biotécnica priva de significado o pai e a mãe, ou melhor, os reveste de um significado i-natural, que nada tem a ver com a antiga relação de filiação. Isso que parecia impensável ocorreu, não existe mais um direito de conhecer o próprio pai ou a própria mãe. Ambos podem permanecer ignorados, porém o nascituro terá um pai e uma mãe que não serão mais naturais, mas determinados pela artificialidade do direito, por um critério diverso da imputação do filho aos genitores.

É que eventos que, ao longo da história, foram marcados pelo mistério - vida, corpo, nascimento, morte - são, agora, dessacralizados e reduzidos à calculada objetividade. Eles não nos vêm mais dados de fora ou do alto (de qualquer coisa que chamávamos divina ou destino), mas são por nós produzidos: não os encontramos, mas os fazemos. Esta insaciável vontade de produzir estendeu-se das coisas aos homens, colocando o corpo entre as coisas factíveis. Um pequeno clássico da filosofia estóica, 
o Manuale de Epiteto, inicia com a distinção entre "as coisas que dependem de nós e aquelas que não dependem". O corpo está inserido entre aquelas coisas que - como coloca, em elegantíssimo latim, Angelo Poliziano - nostra opera non sunt (não são nossas obras). Mas a técnica rompeu com a rigidez desta antítese, fazendo do corpo um "nostrum opus" (trabalho nosso), uma coisa produzível. Ele também depende de nós. O Direito não pode permanecer como um curioso espectador, nem delegar a outras forças a condução dos homens. Os tempos exigem que se assuma uma posição. A escolha entre "agir como barreira" ou "cavar um leito na correnteza" está confiada à responsabilidade políticojurídica: não existe qualquer critério sólido e imutável de verdade. Acendem-se, ao redor destas questões, conflitos de fé religiosa, de ideologias, de visões de mundo.

Ao jurista resta a humildade do silêncio.

\section{TECNODIREITO}

1.

"Unusquisque tantum juris habet, quantum potentia valet" (cada um tem tanto Direito, quanto lhe garante a sua força). As famosas palavras de Baruch Spinoza (Tractatus politicus, H, 8; III, 2) sintetizam a própria natureza do direito. Em todos os fenômenos jurídicos - dos mais simples e elementares aos mais solenes e complexos, dos acordos entre particulares às normas legislativas e constitucionais -, encontramos uma relação de vontade. Uma vontade que exige que outra pessoa tenha uma determinada conduta, e, portanto, que queira de um outro modo. O Direito é domínio sobre a vontade dos outros, dos governantes sobre a vontade dos governados, dos credores sobre a vontade dos devedores, dos proprietários sobre a vontade de todos os demais (erga omnes. propriamente), dos juízes sobre a vontade das partes em litígio e assim por diante. As vontades dos outros são chamadas à obediência, isto é, a acolher em si uma vontade dominante e a traduzir-lhe o conteúdo em realidade atuante.

Mas por que uma vontade sobrepõe-se à outra? E por que esta última assume a direção determinada pela primeira? Uma vontade vale mais que outra. $\mathrm{O}$ valor não advém do alto, de uma delegação metafísica ou transcendente, mas de si mesmo, da sua própria historicidade. A vontade dominante - "potenta valet" - vale pela forca, pela capacidade diretiva e coercitiva. A força institui o valor; o valor é a medida da força (... tantum... quantum...). O valor é mera faticidade da força. 
Três palavras, retiradas da frase spinoziana e decisivas na filosofia de Nietzsche, nos permitem compreender o Direito: vontade, força e valor. A vontade se expressa e se desenvolve pela força e, assim, funda o próprio valor. O sujeito "tantum juris habet" tem uma medida de direito equivalente à medida de valor, ou seja, ao grau da vontade de força: “quantum potentia valet”. Não existe Direito sem essa vontade, sem essa capacidade de dominar as escolhas dos outros. Propriamente, o outro, o governado, o devedor dos nossos exemplos, encontra-se diante de múltiplos caminhos e possibilidades de ação, mas apenas um desses é sustentado por uma vontade, que o submete e o domina, e ele a escolhe e a executa. A obediência nasce sempre de um cálculo de forças, sujeita a um domínio imperativo. O Direito é uma força de dirigir, de indicar o caminho à vontade dos outros.

Não um teórico ou um filósofo do Direito (que, como os positivistas, também têm passo pesado e lento), mas um intelectual eclético, que vaga pelo pensamento, Walter Benjamin afirmou a natureza cruel da lei. As páginas de Per la critica delia violenza, publicadas em Ângelus Novus, nos dizem que a violência institui, mantém e depõe o direito: não existe fenômeno jurídico no qual não se expresse e desenvolva a violência. Também no contrato, firmado pelas partes em pacífica cotidianidade, amplia-se a sombra da violência, o "Direito - escreve Benjamin - de recorrer, de qualquer forma, à violência contra a outra [parte], caso ela violar o contrato". A violência é força criadora e destruidora, mas, quando destrói uma velha ordem ou abate um sistema de normas, ela suscita um novo Direito e o defende frente a outros interesses e vontades, ou seja, contra uma violência diversa, que tem em si a mesma capacidade destrutiva e criativa. A História do Direito coincide, plenamente, com a história cíclica da violência.

2.

A vontade, da qual nasce e se desenvolve o direito, procura alcançar um objetivo. Vontade de objetivo - poder-se-ia dizer - escolhe meios e instrumentos adequados. Este é já um primeiro encontro com a técnica, se por técnica entendermos a adequação dos meios aos fins, o não ficar aquém nem ir além do resultado esperado. A força normativa não é desperdiçada e tampouco economizada, mas colocada ao serviço racional do objetivo.

A técnica do direito está propriamente nesta adequação, no pretender a vontade dos outros, nem menos e nem mais do que o sacrifício necessário. A análise económica do direito- que, atualmente, está na moda - levanta um velho e secular problema. E logo acrescenta que a escolha racional dos meios nada tem a ver com a 
escolha racional dos fins: o fim oferece o critério para calcular a racionalidade dos meios, mas não existe qualquer critério para calcular a racionalidade dos fins. Aqui, ao preferir um a outro fim, ou ao ordenar segundo um, primeiro, e outro, depois, se agita a história do homem: fé religiosa, visões de mundo, ideologias políticas, interesses econômicos. Conflitos se acendem e se apagam, alianças são feitas e desfeitas, e alianças e conflitos deixam vestígios na história das legislações.

3.

Mas tecnodireito não indica (ou não quer somente indicar) a técnica do Direito, o racional emprego de meios em vista de um fim. É. acima de tudo. a palavra com a qual descrevemos a situação do Direito no nosso tempo, a relação da forca jurídica com outras forças. Existe entre elas uma característica comum: a vontade consciente de dominar coisas e homens, natureza e história. Vontade, jamais saciada e aplacada, que passa de objetivo em objetivo e não-reconhece qualquer vínculo antes de si e sobre si.

Esta vontade é a própria essência da técnica. Não no velho e incolor significado de escolha de meios coerentes ao fim, mas de vontade dominadora do mundo, daquele mundo que está ao nosso redor e do qual nós mesmos fazemos parte. A técnica é força que usa o mundo e, por isso, o calcula, o governa, o manipula. Todos os diagnósticos e definições da técnica - que foram propostos por filósofos, historiadores e sociólogos, ao longo do século XX - gravitam sobre essa insensata vontade de domínio, que cria o próprio mundo. sobrepondo-o e im-pondo-o à realidade "dada". Daqui, a antítese ou dualismo entre natural e artificial, entre as coisas como seriam primeiro e as coisas como são depois da intervenção da técnica, entre a ingenuidade originária e a reflexão calculante.

E propriamente artificial é o mundo da técnica, isto é, "feito-com-arte", com métodos e habilidade sugeridas pela ciência, e com o auxílio dos meios mecânicos. A “i-naturalidade", assim dolorosamente advertida nas descrições do nosso tempo, não é outra senão aquela do domínio técnico, é a mesma técnica que se desvela na sua medida planetária. E também isso é um traço comum ao Direito, o qual, em face dos seus comandos e proibições, cria o próprio mundo. Um mundo de vontade e de ações, que nada tem de originário e natural. Suprema e pura é a artificialidade do Direito, deste seu julgar as ações (lícitas ou ilícitas, obrigatórias ou livres), deste indicar inesperados caminhos à vontade dos outros. 
4.

O problema é, então, entender se a técnica é uma força unitária, que tudo abarca e resolve em si, ou se ela se distingue em diversos campos e assume múltiplas faces. A vontade de domínio - e só refletir - desenvolve-se em múltiplas formas, e estas ora se encontram em estreitos em acordos, ora são levadas uma contra a outra em ásperos conflitos. Meditemos, a título de exemplo, sobre a hipótese de que a Ciência tenha descoberto uma substância médica que seja considerada vantajosa às empresas farmacêuticas, mas seja adversa e tida como ilícita pelo Direito vigente. Aqui, a técnica assume diversas formas, enfileirando em batalha três autônomas forças, Medicina, Economia e Direito. Elas, embora se reconheçam na vontade de domínio que as anima e impulsiona, encontramse opostas e discordes. O êxito dá luta não é previsível; não sabemos se o direito, isto é, a força político-jurídica, será capaz de efetuar a própria proibição e de convertê-la em execução contra relutantes vontades ou se, ao contrário, virá batida pelas outras forças e submetida à aliança com a Medicina e a Economia.

Disse-se "força político-jurídica", pois o direito, ao menos na secular História do Ocidente, expressa a vontade política, as escolhas daqueles que assumem o governo da coisa pública. Da política, o Direito não pode sair, desta ou daquela política (liberal ou autoritária, conservadora ou progressista); e, quando parece que dela se desliga e se livra, é apenas para abraçar uma outra política e a ela se entregar. Revezaram-se, no século passado, os profetas do destino (de Weber a Rathenau e a Schmitt), os espíritos capazes de levar o olhar além dos limites, e nos falaram de economia, ou política, ou técnica como destino do mundo. Não viram nem falaram em vão, pois perceberam as forças em campo e as descreveram na alternância entre vencer e sucumbir, entre se sobrepor e se submeter aos outros. O destino não se deixa resumir em uma palavra, estando, acima de tudo, neste jogo de forças, de modo que nenhuma delas possa ditar lei às outras, e todas devem remeter-se ao êxito da história, ao hegeliano tribunal do mundo.

5.

A asserção autonomia da política, que é, depois, autonomia do direito relativa a outras forças terrenas, rejeita toda ilusão ou ameaça tecnocráticas. Não existe "experto" ou "competente" que esteja em grau de se sub-rogar à luta política e de determinar o conteúdo das normas jurídicas. $\mathrm{O}$ tecnocrata ou burocrata, que realiza ou sugere uma certa escolha jurídica, faz, e não pode não-fazer, a própria política. A antipolítica, corriqueira nos 
ambientes econômicos e financeiros, é apenas uma forma da política, uma dissimulação atrás das mesas de estatísticas ou cálculos de custos e benefícios.

A escolha dos fins pertence à política; burocratas e teóricos podem apenas socorrer na escolha dos meios, ou seja, para estabelecer a racional coerência destes com aqueles. Os problemas da convivência, de nos encontrarmos juntos com os outros, são suscetíveis de múltiplas respostas: cada uma ditada pelas visões de mundo ou fé religiosa ou ideologias. Não existe nenhum critério superior, que, na sua objetiva e pacífica neutralidade, permita escolher entre uma e outra resposta, e portanto seja acessível e útil para os "expertos" da política. Permanece a luta entre soluções opostas e discordantes, o contraste entre partidos, o gosto das seitas pela intransigência, a capacidade de sacrifício: em suma, aquele nó de idéias e de paixões que estamos acostumados a reunir sob o nome de política. Somente o "profano" pode decidir sobre as controvérsias entre técnicos; somente à política cabe a determinação dos fins: o ideal de tecnicidade - repetimos com Kelsen - “foi, em todos os tempos, uma das mais potentes ideologias da autocracia". Se a política abdica, não substitui a técnica, mas uma outra política dissimulada atrás da especialidade dos "competentes" e dos "expertos".

Dizer que o Direito é técnica, isto é, forma de vontade de força, significa dizer que ele é política e que expressa a relação entre governantes e governados. E, por isso, rejeitar a ingenuidade ou perspicácia tecnocráticas, as quais, confundindo a escolha funcional dos meios com a escolha história dos fins, sub-rogariam o lugar das ásperas e cruéis lutas da política com "debate", "seminários", "mesas-redondas" de "expertos" e "competentes".

6.

Disse-se, anteriormente, que a vontade de força, este impulso vital de dominar e usar, assume formas múltiplas e diversas. O Direito (e, aqui, volta-se ao início do nosso discurso) é uma entre as formas de vontade de força: não se exercita e desenvolve sobre as coisas ou sobre a natureza animal ou vegetal, mas sobre a vontade mesma do homem. O Direito quer que o outro queira de um certo modo, é vontade dominadora de uma outra vontade, a qual impõe um específico conteúdo. A partir do que escreve um grande filósofo do Novecentos, Giovanni Gentile, “o Direito pode ser entendido como a natureza do mundo da vontade", entendemos que o direito trata a vontade dos outros da mesma maneira como a técnica trata a natureza. O direito "naturaliza" a vontade, a calcula e a manipula como um ente do mundo externo. 
Isso é propriamente tecnodireito, a técnica da forma do Direito, a vontade de domínio sobre as vontades dos outros. Existe qualquer coisa de terrível e de ímpio: enquanto as outras formas de técnica voltam-se à natureza - e também àquela parte da natureza que é o corpo humano -, aqui, no Direito, a vontade procura determinar o conteúdo do próprio querer. A regra é ditada por uma vontade; o regulado é uma outra vontade. A técnica instala-se entre as vontades humanas.

\section{7.}

Nisso, que denominamos regulado, a matéria sobre a qual se desenvolve a técnica do direito, recai também as outras formas de técnica, ou seja, para usar uma linguagem mais simples e genuína, vontade dos cientistas e dos empreendedores, campos do saber e da economia. Essas formas não se deixam docilmente dominar, mas exprimem a sua força e a opõe ao Direito. Pode se abrir, assim, uma luta áspera e grandiosa, que freqüentemente se amplia a outras forças: fé religiosa, círculos de cultura, seitas místicas, agitações populares.

$\mathrm{O}$ direito encontra diante de si a técnica e a economia juntas e aliadas, a tecnoeconomia, através da qual a Ciência oferece às empresas novos métodos e descobertas, e as empresas solicitam e sustentam as pesquisas da Ciência. A tecnoeconomia quer ser, ela mesma, normativa e determinar o conteúdo do Direito. As normas jurídicas, emanadas do poder político (qualquer que seja, autoritário ou democrático), são aceitas ou recusadas segundo o favorecimento e a alteração do funcionamento do mercado. A economia de mercado assume o lugar do velho Direito Natural e, assim sendo, eleva-se a juiz do direito positivo, tutelando a sua conservação ou promovendo a sua reforma. O regulado inverte, ou tenta inverter, a relação com o regulante, e dar a si a própria regra. As leis naturais da economia, ressuscitando os pálidos fantasmas do Direito Natural, tendem a colocar-sé além e sobre o poder jurídico-político.

Por que lutas entre partidos, choque de visões da sociedade e da vida, divisões e desencontros, se das leis naturais da economia é que são dedutíveis as justas e oportunas normas do Direito? Se esta tarefa pode ser confiada ao neutro e pacificante trabalho dos “expertos" e "competentes"? Retorna, assim, o ingênuo ou astuto ideal de tecnicidade, e as tecnocracias se preparam para substituir parlamentares e governos representativos.

Eis, aqui, a força que hoje o Direito encontra diante de si ou contra si e com a qual se inicia a partida decisiva. 
8.

A tecno-economia apresenta um caráter que é inesperado e novíssimo na história do homem. Poder-se-ia chamar espacialidade, o seu expandir-se e alastrar-se sem limite algum, a deslimitacão. A rede telemática, sem lugares e ancoragens geográficas, nesse contexto, é o símbolo mais seguro e adequado. Enquanto a força político-jurídica mantém-se ainda dentro da limitação, falando e agindo na linguagem da territorialidade, a tecno-economia amplia sobre o globo o seu próprio espaço. Trata-se dos temas do geodireito, que serão apresentados e analisados em outra dessas lições brasileiras.

Aqui, deve apenas se dizer que o Direito, vivido ao longo de séculos dentro dos limites dos Estados, encontra-se admirado e perdido. Como perseguir e capturar os fenômenos da tecno-economia? Como nos tornarmos iguais ou similares na vontade de domínio planetário? Pertence ao Direito (e, antes de tudo, é sua natureza profunda) o caráter de artificialidade que agora se revela como instrumento rápido e audacioso. A artificialidade, libertando-se passo-a-passo dos vínculos terrestres e das tradições históricas, está também em condição de superar os limites e de instituir uma espacialidade jurídica. Os acordos entre Estados e a criação de entes, organismos e autoridades supranacionais voltam-se a este objetivo. O antigo nomos, segundo Cari Schmitt, vinculava o Direito aos lugares, à histórica determinação de uma ou outra comunidade; o novo nomos, se pretender co-estender-se junto à tecno-economia e assumir a sua própria medida, deve desligar-se daqueles vínculos e desfrutar, plenamente, o intrínseco caráter da artificialidade.

9.

O tecnodireito é uma entre as formas de vontade de força, um dos centros-deforça que lutam pelo domínio do mundo. “Tecno", pois ele é agitado por aquele demônio, e vibrante por causa daquela insaciada energia, da qual provém também as outras forças. Se as ciências e as técnicas naturais usam e manipulam as coisas ao redor - o ar, a água, a terra e mesmo o corpo do homem -, o Direito tem a suprema ambição de empregar pelos própriosobjetivos as vontades dos outros. Esta é a eterna índole do poder político-jurídico, isto é, de um poder ordenador do nosso viver comunitário.

O tecnodireito é definido como tecnopolítica, e o empenho histórico do direito como responsabilidade da política. Quem saudou com alegria o pôr do sol das ideologias, não sabia (ou, então, sabia muito bem) que aqueles lugares não permaneceriam vazios para sempre e que outras forças - a economia e a técnica - os ocupariam rapidamente. Agora, que a consciência das ilusões ou dos enganos parece madura, pode levar-se o apelo 
à política: que retome nas próprias mãos o destino do homem e restaure, com isso, o domínio do Direito. Será que esse apelo nunca será escutado?

Ninguém está em condições de conhecer o futuro. Todos estamos à espera.

\section{GEODIREITO}

1.

Nos questionamos porque o problema do espaço tem assumido tão grande e inesperada importância nos estudos e nas práticas do Direito.

É preciso começar de longe. Somos educados ou habituados a raciocinar com base em um critério: o Estado exercita a própria soberania sobre uma porção da superfície terrestre. A soberania se expressa, maximamente, na forma de lei. O território estabelece a medida do "senhorio jurídico" do Estado.

Destaca-se, assim, uma dimensão espacial do direito, correlativa à dimensão espacial do Estado. O território determina o âmbito de um e de outro. As normas jurídicas - deve-se recordar - vigem no tempo e no espaço: têm sempre necessidade de um "quando" e de um "onde". Elas são emanadas, modificadas, ab-rogadas e, por isso, apresentam uma duração, mais ou menos breve, mais ou menos longa. Conjuntamente elas têm a necessidade de uma determinação espacial, isto é, de um campo de vigência, municipal, regional, nacional, e assim por diante. A norma jurídica é sempre norma em um certo lugar e por um determinado tempo.

2.

Dissemos que o terrritório calcula a dimensão espacial do Estado e do Direito.

Mas o que é verdadeiramente o território? E como se isola e se individua sobre a plana superfície do globo?

Os dicionários da nossa língua indicam a etimologia do termo latino "terra". Não sei se é exato, mas prefiro seguir o pensamento de um grande jurista: "Territorium deriva de térreo ou territo. Jus terrendi é usado como sinônimo de jus imperíi. O significado literal de territorium. como a própria desinência revela, é o âmbito do senhorio". ${ }^{4} \mathrm{O}$ território

4 PERASSI, Tomaso. Scritti giuridici. Milano: Giufrrè, 1958. v. 1, p. 103. 
aparece como o lugar em que o poder provoca terror e medo; em que o "senhor" dita normas e ameaça sanções.

Isso que constitui um território e o faz o lugar de uma determinada senhoria é o limite.

Não existe território sem limites. A superfície terrestre, em seu crepúsculo originário e primordial, se apresentaria plana, lisa e indistinta. Uniforme, de apenas uma única forma, pois ainda não existem as plurais e diversas formas introduzidas pela História humana. O limite (ainda que coincida com os limites naturais: cursos dos rios, cadeias de montanhas, margens dos rios, etc.) é sempre inatural: criatura da História, que rompe a originária uniformidade e determina a individualidade dos lugares.

3.

O limite desenvolve uma função dúplice: excludente e includente. Ele exclui, pois divide e separa o meu e o outro. O outro é aquilo que é além do limite: o oculto, o misterioso, o perigoso. Existem caráteres profundos e afins entre propriedade e soberania. A exclusividade é comum a ambos. O art. 832 do Código Civil italiano, reunindo a tradição secular, define a propriedade como "direito de gozar e dispor das coisas de modo pleno e exclusivo". Na defesa da propriedade, o art. 950 prevê a ação de regulamentação de limites; e o art. 951, a ação para demarcação de limites, isto é, dos sinais materiais e visíveis onde o meu se distingue do outro.

Do mesmo modo, exclusiva é a soberania estatal. Não é concebível um concurso de soberania, uma pluralidade de senhores sobre o mesmo território. Aqui, vige o aut-aut. ou a soberania de um Estado ou a soberania de outro Estado. Se olhamos os Estados do alto, como expectadores de uma paisagem, eles aparecem um ao lado do outro; se ao contrário - como sempre acontece na nossa experiência de cives - nos colocamos no interior de um Estado, este é único e exclusivo. Na avaliação das nossas ações, ao julgar sua legalidade ou ilegalidade, não podemos adotar pontos de vista diversos ou discordantes, mas apenas um único ponto de vista: aquele, propriamente, do Estado, que queremos e ao qual nos sentimos pertencentes.

4.

O limite, exercitando a função includente, estabelece unidade e identidade daquilo que está dentro. Língua, costumes, tradições concorrem na individualização desse 
lugar e na separação dos outros. Assim, se determina o pertencimento, o sentir-se parte de um todo, daquele mundo no qual os limites se fecham e reinserem.

O símbolo da inclusão - símbolo, como mostrou Tullio Gregory, cheio de sacralidade e de mistério - é a "porta": porta da cidade ou da casa, limite além do qual vive o outro. Este vem de fora, forasteiro, e pede para passar pela porta ou a contorna ou a derruba com violência de guerra. Excluir ou incluir - as duas funções do limite se relacionam com profunda reciprocidade: aqui nascem as idéias de dentro e fora, de pertencimento e estranhamento.

5.

O território estatal também marca a extensão de política e do direito. No "dentro dos limites" se agitam as lutas entre partidos e se determinam as orientações políticas. Aqui, se expressa a cidadania como participação no destino de um povo ou, mais simplesmente, nos problemas de uma coletividade organizada.

Neste lugar também nascem as normas jurídicas. A luta política conhece, igualmente para cada um, vencedores e vencidos; e os primeiros estabelecem a disciplina jurídica dos interesses. Por detrás de qualquer ordenamento jurídico existe sempre uma vítima do poder. No Estado territorial, como vem se formando na História moderna da Europa, o poder político-jurídico está, também, restrito aos limites, espacialmente definido.

6.

Esta representação - construída em torno a um spatium terminatium, isto é, a um lugar de política e de direito, isolado e identificado pelos limites -, vem dilacerada e arrasada por duas imensas forças, que não conhecem limites, não têm pátria, se expandem para qualquer lugar. Forças da deslimitação, que se chamam técnica e economia, e que, juntas, conjuntas e aliadas, geram a tecno-economia do nosso tempo.

A essência da técnica, como vontade de desfrutar e de manipular o mundo, e a essência da economia (falamos, obviamente, da economia de mercado), como insatisfeita e indefinida vontade de lucro: estas essências, ou formas da vontade, rejeitam o fechamento dos limites e a determinação dos lugares. Elas são radicalmente atópicas, sem lugar, e por isso podem se difundir e se implantar em qualquer lugar. "A civilização - lemos em uma página de Giacomo Leopardi - tende naturalmente a propagar-se e a fazer 
sempre novas conquistas, não podendo estar parada, nem ser contida dentro de qualquer limite, principalmente em relação à extensão".

As transações econômicas ignoram os limites. Enquanto as tribos estão em guerra, entre outras coisas, na escuridão da noite, giram os mercadores, que oferecem bens e os negociam, sentindo-se fora de qualquer pátria. Nesse sentido, Piero Zanini escreveu, em um livro rico e sugestivo sobre os "significados do limite": "A terra de ninguém é aquela que está entre as duas margens, entre as fronteiras de dois países, de dois espaços diferentes. É o lugar onde a norma, a regra que o limite estabelece, não vale mais, a terra selvagem onde cada um deve tomar conta de si mesmo e tudo se torna possível”.

O "qualquer lugar" da economia é (ou aspira a ser) uma indefinida terra de ninguém. No "qualquer lugar" da tecno-economia (onde imperam as insaciáveis e sempre insatisfeitas vontade de lucro e vontade manipuladora do mundo), os indivíduos perdem toda identidade de cidadãos, todo vínculo de pertencimento terrestre. Eles se distinguem somente pela diversidade de funções, pela parte - podemos dizer - dirigida a qualquer um nos mecanismos técnicos ou nas atividades de mercado. A função não demanda individualidade, mas antes teme e rejeita atritos subjetivos e psicológicos. O "funcionar" é garantido por prestações anónimas e fungíveis: nos grandes negócios, nas relações de massa e, agora também, nos campos profissionais em que valiam o prestígio dos indivíduos e as honras de classe, em todos os lugares perto de nós, anda a despersonalizada "eficiência", privada de rosto e de nome.

A rede telemática é o símbolo extremo da aliança tecnoeconômica: espaço artificial sem limite, não lugar, onde a vontade de lucro, desraizada e desterritorializada, se expressa além dos Estados e além do direito dos Estados. Determina-se, assim, uma diferença, uma "defasagem", de extensão: técnica e economia não são coextensivas à política e ao Direito: aquelas, indefinidamente espaciais; estes, definidamente territoriais.

7.

O problema da coextensividade, hoje colocado, foi já percebido por talentosas leituras e presságios. Como não lembrar o livro de Fichte, publicado em 1800, sobre "O Estado segundo a razão ou o Estado comercial fechado?” O grande filósofo leva às extremas consequências o princípio da territorialidade: nada pode sair dos limites do Estado: “o Estado - ele escreve - fecha-se completamente a cada comércio com o exterior e forma, dali em diante, um corpo comercial separado, como até agora formou um separado corpo jurídico e político". Proibida a moeda comum, não admitido o comércio do cidadão 
com o estrangeiro, o Estado se fecha em si mesmo; economia política e direito voltam a co-estender-se, e todos assumem a idêntica medida espacial: "um Estado segundo a razão - esclarece Fichte - é propriamente um Estado comercial fechado, como é, ao final, um Estado fechado no que diz respeito às leis e aos indivíduos que o compõem".

Recordamos o pensamento de Fichte, não-somente para especificar soluções ou propostas de soluções, mas para a lúcida consciência do problema: como tornar coextensivas forças que têm uma diferente medida espacial? Como reconduzir à unidade a limitação da política e do direito e a deslimitação da tecno-economia?

8.

Uma solução do problema é: que a tecno-economia escolha, ela mesma, o seu próprio Direito; e que os Estados ofereçam, quase em uma "corrida pelo desconto", os respectivos ordenamentos. As empresas, colocadas diante do mercado dos ordenamentos jurídicos, escolhem o ordenamento mais vantajoso e conveniente. O “onde jurídico" é determinado pelas empresas, que podem facilmente multiplicá-lo ou ajustá-lo: o primeiro para adquirir recursos financeiros; o segundo, para o custo da mão-de-obra; e depois, ainda, um terceiro diferente, para benefícios fiscais ou emissões de bonds, e o último, enfim, para a disciplina da falência. O "qualquer lugar" do mercado global permite que as empresas escolham - em razão das diversas fases da atividade econômica - uma pluralidade de sedes jurídicas.

O mercado das ordenamentos jurídicos não surge de modo espontâneo e natural. Ele encontra fundamento em uma decisão política, aquela, propriamente, que favorece a vontade de lucro e que deixa às empresas a escolha da sede jurídica. Trata-se, como é obvio, de uma decisão abdicativa, pela qual a classe política renuncia ao governo da economia e se faz governar por ela.

9.

Outra solução (solução - repita-se - para o problema da co-extensividade) dá-se no domínio imperial de um Estado, o qual não somente ocupa mercados sempre mais vastos, mas também institui uma nova ordem. O princípio, ao qual todos os outros se reconduzem, está na segurança, na garantia de funcionamento dos mercados.

A defesa da segurança degrada cada inimigo a criminoso e converte a guerra em operação de polícia. A força imperial não declara guerra aos outros Estados (como 
ocorria nas chancelarias diplomáticas dos últimos séculos), mas provê, acima de tudo preventiva ou repressivamente -, a defesa da própria segurança.

A co-extensão é alcançada através do domínio politico-militar de um grande espaço que, a bem ver, não-ameaça a territorialidade do Estado hegemônio mas, mais do que qualquer coisa, a dilata e a alarga. A nova ordem acompanha a abertura dos mercados e os protege contra ameaças ideológicas e religiosas, econômicas e financeiras.

10.

Desta última vem a solução dos acordos interestatais, isto é, dos entendimentos, pelos quais uma pluralidade de Estados - cada um no exercício da própria soberania - se propõe a capturar a tecno-economia e a ligar suas atividades, reciprocamente, a singulares e específicos lugares.

Enquanto as empresas observam para escolher a sede das relações jurídicas, aqui é o direito que determina a sede jurídica dos negócios. Não o mercado das ordens jurídicas, mas a ordem jurídica do mercado: ordem alcançada pelos Estados no exercício da soberania e garantida pela sua força coercitiva.

À solução fichtiana do "Estado comercial fechado", ao domínio políticomilitar do império, os acordos interestatais contrapõem a pluralidade de territórios e a uniformidade de disciplina jurídica. Os territórios restam diferentes e múltiplos, na mesma medida em que múltiplos e diferentes são os Estados; mas a disciplina jurídica se mostra uniforme, ou seja, assume o mesmo conteúdo. Pluralidade, a bem ver, de direitos idênticos.

11.

A solução dos acordos interestatais (as outras duas, do "Estado comercial fechado" e do domínio imperial, poderia-se dizer intraestatal) exige que o direito assuma um alto grau de artifícalidade.O ponto é de extraordinária importância. A relação profunda que Cari Schimtt denominou "nomos da terra" conjuga o Direito a lugares historicamente determinados. A gênese do Direito está em uma ordem concreta, na primeva ocupação e distribuição de terra. As normas vêm depois. O Direito tem uma existência terrestre; é um modo de ordenar o espaço. "O nomos - Carl Schmitt no grande livro de 1950 - é, portanto, a forma imediata na qual se coloca espacialmente visível o ordenamento político e social de um povo". Terra, povo e direito se constituem numa concreta unidade espacial. 
Mas como pode o direito, ligado à historicidade de um povo e à determinação de um lugar, perseguir e capturar os negócios da tecno-economia, que não têm nem pátria nem limites? Como pode a regra se submeter ao regulado?

Não existe outro modo a não ser pela dor do desenraizamento, pela assunção da artificialidade como essência constitutiva do Direito. A artificialidade, o artefato, é o caráter fundamental da tecno-economia, da vontade, isto é, de manipular o mundo e de conseguir indefinidos lucros. Se a norma jurídica se desliga do vínculo terrestre, da conexão genética com lugares singulares; se ela se reduz por inteiro à vontade do homem, então se coloca em grau de afrontar a tecno-economia. De afrontá-la, não mais de um plano diverso, mas sobre o mesmo plano, que é aquele da vontade, desenraizamento, deslimitação.

O espaço jurídico adquire, assim, um novo e inédito significado. Ainda se parte e se retorna ao território dos Estados (daqueles Estados, propriamente, que têm feito acordos de "uniformização"), mas a uniformidade da disciplina exige o sacrifício da identidade histórica do Direito.

O espaço não é mais o lugar originário e constitutivo, mas o simples campo de vigência de uma norma, o âmbito (diria Hans Kelsen) de validade geográfica do Direito. Âmbito, arbitrário e artificial, decidido e estabelecido pela vontade humana. O alto grau de artificialidade, ao reduzir o direito fraterno à essência da tecno-economia, restaura a coextensão entre política, direito e economia. A política que não queira se dobrar à vontade de lucro e oferecer as ordens jurídicas ao cálculo de vantagem ou desvantagem das empresas; que se mantenha longe do fechamento fichtiano e do domínio imperial; não tem outra alternativa senão aquela dos acordos interestatais. E, então, precisa de uma profunda e lúcida consciência da artificialidade jurídica, de vontade capaz de estabelecer o espaço aplicativo do direito. Somente desenraizando-se, desligando-se dos limites territoriais, a vontade normativa pode alcançar aquele grau de artificialidade, que, pela idêntica essência da regra e do regulado, a permite dominar ou orientar a tecno-economia.

Quanto mais o direito permanece ligado, em seus modos e conteúdos, à gênese terrestre, ao nomos histórico, menos ele está em condições de equilibrar o horizonte global da tecnoeconomia. Ao contrário, quanto mais se afasta dos lugares originários e assume caráteres de artificialidade, mais adentra, por assim dizer, na própria natureza da tecno-economia, adquirindo o poder de orientá-la ou governá-la.

A deslimitação do regulado (dos interesses, isto é, que são matéria de disciplina jurídica) exige e invoca a des-limitação da regra; e esta última, para alcançar tal grau de correspondência e adequação, deve libertar-se do abraço terrestre, do fundamento 
originário do nomos. O Direito - em face da força de acordos interestatais - recai, por assim dizer, sobre os territórios dos singulares Estados e estabelece regras uniformes, que esquecem de cada situação e conexão histórica. Nesse sentido, assinala Massimo Cacciari: "A liberdade comercial, financeira e econômica, que faz de cada lugar e de cada tempo uma globale Zeit, está em irremediável conflito com o positivismo do direito ligado ao Estado". A solução desse conflito não exige a ultrapassagem ou o abandono do positivismo jurídico (e que outra corrente estaria pronta para substituí-lo e tomar o seu lugar?), mas, mais do que tudo, o seu extremo e radical empenho. Somente a artificialidade do Direito, como produto do querer humano, arbitrário e incondicionado, pode desfazer a relação entre norma e fundo terrestre. Somente ela pode determinar, gradualmente, a dimensão espacial do Direito.

Existe uma alternativa iniludível: ou o Direito, fiel às antigas raízes, se retira à sombra, perdido e inerme diante da imensa força da tecno-economia, que escolherá, ela, a sede jurídica das suas transações; ou o Direito, nas formas do domínio imperial ou dos acordos interestatais, será capaz de alcançar aquela força e de dobrá-la à sua própria disciplina.

Outra coisa, o jurista não pode dizer; outra coisa, o jurista não sabe prever.

São Paulo, abril de 2007. 